\title{
APA PERTIMBANGAN MASYARAKAT BERASURANSI SYARIAH DI JABODETABEK?
}

\author{
Tati Handayani, Fitri Yetty, dan Prima Dwi Priyatno \\ Universitas Pembangunan Nasional Veteran Jakarta \\ Jl. RS. Fatmawati Raya, Pd. Labu, Kec. Cilandak, Kota Depok, Jawa Barat 12450 \\ Email: primadpriyatno@upnvj.ac.id
}

\begin{abstract}
The presence of sharia insurance becomes one of the choices of muslim community in investing, because insurance as one of the investment ways to face risks in the future. The success of sharia insurance companies are cannot be neglected from the participation of people in understanding the importance of taking sharia insurance. The research aims to discover and analyzing factors that can influence people's perception of using Islamic insurance. The research method used is quantitative descriptive analysis. For population and sample are Jabodetabek community. This method uses Convenience Sampling Technique, and the data analysis uses Partial Least Square (PLS). This research shows that the most important factor which is influencing the community in deciding to take Sharia insurance is the level of understanding of sharia continued with the level of product quality, but it can be seen that the premium and promotion indicators are still less known by the respondent. So, the insurance company need to be more socialize sharia insurance to the public.
\end{abstract}

Keywords: premium, contribution, product, promotion, sharia, sharia insurance

\begin{abstract}
ABSTRAK
Kehadiran asuransi syariah menjadi salah satu pilihan masyarakat muslim dalam berinvestasi, karena asuransi merupakan salah satu cara investasi untuk menghadapi resiko di masa yang akan datang. Keberhasilan perusahaan asuransi syariah tidak bisa luput dari peran serta masyarakat dalam pemahaman akan pentingnya berasuransi syariah. Penelitian ini bertujuan untuk mengetahui dan menganalisis faktor-faktor yang dapat memengaruhi persepsi masyarakat untuk menggunakan asuransi syariah. Metode penelitian yang digunakan adalah analisa kuantitatif. Untuk populasi dan sampel adalah masyarakat Jabodetabek menggunakan Teknik Convenience Sampling dan untuk analisis data menggunakan PLS (Partial Least Square). Penelitian ini menunjukkan bahwa faktor paling signifikan yang memengaruhi masyarakat dalam memutuskan untuk berasuransi syariah adalah tingkat pemahaman tentang syariah dilanjut dengan tingkat kualitas produk, namun dilihat dari indikator premi dan promosi masih kurang diketahui oleh responden, sehingga perusahaan asuransi harus lebih mensosialisasikan asuransi syariah ke masyarakat.
\end{abstract}

Kata kunci: premi / kontribusi, produk, promosi, syariah, asuransi syariah 


\section{PENDAHULUAN}

Asuransi sendiri, awalnya merupakan cara atau usaha mempersiapkan dalam menghadapi risiko yang telah disepakati sekelompok orang, bersepakat untuk menaggung bersama atas risiko apabila ada salah satu dari kelompok tersebut tertimpa musibah. Asuransi pada awal mula dikenal berupa asuransi kebakaran, yaitu di Eropa Barat, kemudian pada abad ke 13 dan 14 terjadi peningkatan transportasi jalur laut baik untuk mengirim barang atau pengantaran orang antar pulau sehingga berkembang pula asuransi pengangkutan laut yang berasal dari Romawi. Jenis asuransi pada saat itu yang berkembang adalah jenis asuransi kaputalis, dimana asuransi dibentuk untuk mendapatkan keuntungan dan didasarkan atas perhitungan niaga. Pada abad ke 19 barulah dikenal istilah asuransi jiwa (Ridlwan, 2017).

Dalam perkembangannya, asuransi bertransformasi menjadi sebuah lembaga keuangan dalam pengelolaan risiko. Asuransi termasuk kedalam golongan lembaga keuangan bukan bank, sebagai lembaga keuangan, asuransi memiliki fungsi dan karakteristik tersendiri jika dibandingkan dengan lembaga keuangan lainnya, yaitu dalam mengelola atau pengalihan risiko dari nasabah sebagai tertanggung (original risk bearer) pada perusahaan asuransi sebagai penanggung.

Asuransi konvensional, perusahaan asuransi mengumpulkan atau menarik dana dari para nasabah berupa premi yang dibayarkan secara berkala, dengan imbalan penanggungan risiko dengan ganti rugi dari perusahaan asuransi apabila telah terjadi risiko, besaran nilai ganti rugi telah disepakati diawal antara nasabah dan perusahaan asuransi, dengan demikian transaksi tersebut merupakan perpindahan risiko (transfer of risk) dari nasabah kepada perusahaan asuransi. Hal ini berbeda dengan asuransi syariah, dimana dalam transaksinya mempunyai semangat kebersamaan yaitu saling tolong menolong (ta'awun) dalam kebaikan, pada transaksinya asuransi Syariah mempunyai dua akad terpisah antara nasabah dengan perusahaan asuransi dan antar sesama nasabah. Perusahaan asuransi syariah hanya sebagai administrator dalam mengelola dana nasabah, dimana nasabah mempercayakan dana berupa kontribusi secara berkala, kontribusi tersebut merupakan hibah nasabah untuk kemudian dikelola oleh perusahaan asuransi syariah, sehingga pada implikasinya tidak adanya perpindahan risiko (transfer of risk) dari nasabah kepada perusahaan asuransi.

Kehadiran asuransi syariah menjadi salah satu pilihan masyarakat, khususnya bagi umat muslim yang diperintahkan untuk memperhatikan semua aktifitas kehidupannya, termasuk transaksi-transaksi muamalah yang dilakukan agar tidak melanggar ketentuan-ketentuan syariah. Asuransi salah satu cara investasi untuk menghadapi resiko di masa yang akan datang. Hal ini sesuai dengan perintah Allah SWT agar membuat perencanaan untuk berusaha mempersiapkan diri dalam menghadapi hari esok, pada al-Quran surat al-Hasyr ayat 18 disebutkan: 


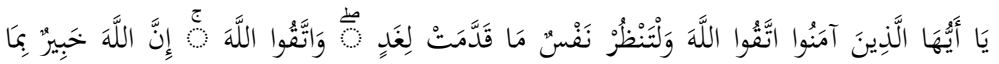 تَعْمَلُونَ (الحشر :18)}

Hai orang-orang yang beriman, bertakwalah kepada Allah dan hendaklah setiap diri memerhatikan apa yang telah diperbuatnya untuk hari esok; dan bertakwalah kepada Allah, sesungguhnya Allah Maha Mengetahui apa yang kamu kerjakan. (QS AlHasyr:18)

UU no 40 tahun 2014 tentang asuransi syariah, menjelaskan definisi asuransi syariah sebagai berikut:

"Asuransi syariah adalah kumpulan perjanjian, yang terdiri atas perjanjian antara perusahaan asuransi dan pemegang polis dan perjanjian di antara para pemegang polis, dalam rangka pengelolaan kontribusi berdasarkan prinsip syariah guna saling menolong dan melindungi."

Sedangkan asuransi syariah didalam Fatwa Dewan Syariah Nasional Majelis Ulama Indonesia (DSN-MUI) No. 21 tentang Pedoman Umum Asuransi Syariah mendefinisikan:

"Asuransi syariah adalah usaha saling melindungi dan tolongmenolong di antara sejumlah orang/pihak melalui investasi dalam bentuk aset dan atau tabarru' yang memberikan pola pengembalian untuk menghadapi risiko tertentu melalui akad (perikatan) yang sesuai dengan syariah.” Dewan Syariah Nasional (DSN), (2001)

Perkembangan industri syariah di Indonesia menunjukkan peningkatan yang positif, seiring dengan banyaknya pertumbuhan perusahaan asuransi syariah. Hal ini didorong juga dengan adanya peraturan Otoritas Jasa Keuangan (OJK) tentang pemisahan Unit Usaha Syariah (UUS) perusahaan asuransi menjadi perusahaan sendiri paling lambat akhir Oktober 2024, aturan tersebut tertuang dalam Undang-Undang Nomor 40 Tahun 2014 tentang Perasuransian dan Peraturan OJK Nomor 67/POJK.05/2016. Pertumbuhan asuransi syariah pada beberapa tahun terakhir di Indonesia dari beberapa aspek dapat dilihat pada tabel berikut.

Tabel 1. Data Keuangan Asuransi Syariah (Miliar Rp)

\begin{tabular}{lllllr}
\hline \multicolumn{1}{c}{ Indikator } & \multicolumn{1}{c}{2015} & 2016 & 2017 & \multicolumn{1}{c}{2018} & Sep-2019 \\
\hline Aset & 26.519 & 33.244 & 40.520 & 41.959 & 44.411 \\
\hline Investasi & 23.070 & 28.807 & 35.310 & 36.969 & 38.994 \\
\hline Kontribusi & 10.489 & 12.028 & 13.995 & 15.369 & 11.744 \\
\hline Klaim & 3.342 & 4.336 & 4.948 & 7.583 & 7.338 \\
\hline
\end{tabular}

Sumber: Data statistik IKNB Syariah - Otoritas Jasa Keuangan (OJK) 
Data keuangan asuransi syariah diatas menunjukan peningkatan positif dalam perkembangan industry asuransi syariah di Indonesia, dari sisi aset kenaikan dari tahun 2015 hingga september 2019 jika dinilai rata-ratanya aset perusahaan asuransi syariah naik sebesar $14.16 \%$ dan rata-rata kenaikan nilai investasinya naik sebesar $14.40 \%$.

Tabel 2. Data Industri Asuransi Syariah September 2019

\begin{tabular}{|c|c|c|c|}
\hline Keterangan & $\begin{array}{l}\text { Industri Syariah } \\
\text { (Full Fledged) }\end{array}$ & $\begin{array}{c}\text { Unit Usaha } \\
\text { Syariah }\end{array}$ & Aset (Miliar RP) \\
\hline Asuransi Syariah & 13 & 49 & 44.411 \\
\hline $\begin{array}{l}\text { Asuransi Jiwa } \\
\text { Syariah }\end{array}$ & 7 & 23 & 4.626 \\
\hline $\begin{array}{l}\text { Asuransi Umum } \\
\text { Syariah }\end{array}$ & 5 & 24 & 2.541 \\
\hline Reasuransi Syariah & 1 & 2 & 1.952 \\
\hline
\end{tabular}

Selain data keuangan, dapat pula dilihat dari peningkatan jumlah perusahaan asuransi yang beroprasi di Indonesia. Hingga saat ini perusahaan asuransi syariah full fledged ada 13 emiten yang terdiri dari 7 perusahaan asuransi jiwa syariah, 5 perusahaan asuransi umum syariah dan 1 perusahaan reasuransi syariah. Sedangkan untuk perusahaan unit usaha asuransi syariah ada 50 emiten, terdiri dari 23 perusahaan asuransi jiwa unit usaha syariah, 25 perusahaan asuransi umum unit usaha syariah dan 2 perusahaan unit usaha reasuransi syariah.

Di Indonesia sendiri asuransi syariah sudah berjalan selama 22 tahun, pertama kali diresmikannya PT. Takaful Keluarga sebagai awal mula lahirnya asuransi berasas syariah yaitu pada tahun 1994. Usia tersebut masih tergolong sangat muda jika dibandingkan dengan dengan asuransi konvensional yang sudah beroperasi sejak tahun 1912 dengan berdirinya asuransi Bumiputera. Pertumbuhan asuransi syariah dinilai positif dan masih mempunyai peluang pasar yang cukup besar (Ichsan, Syarif, \& Jakarta, 2016). Mengingat Indonesia merupakan negara muslim terbesar di dunia, hal ini menjadi tantangan tersendiri bagi industry asuransi syariah dalam memasarkan produknya di pasar muslim terbesar, namun demikian pasar asuransi syariah tidak hanya sebatas umat muslim saja, namun juga bagi non muslim.

Perkembangan positif asuransi syariah di Indonesia, jika dibanding dengan negara-negara lain masih dapat dibilang kurang, hal ini karena minat masyarakat di Indonesia akan pemahaman dan literasi pentingnya berasuransi masih kurang, keberhasilan perusahaan asuransi syariah di Indonesia yang ada tidak bisa luput dari peran serta masyarakat yang memiliki kesadaran yang cukup tinggi akan pentingnya berasuransi. 


\section{TELAAH TEORITIS}

Keputusan masyarakat dalam memilih untuk berasuransi syariah, tidak lepas dari perkembangan industri keuangan syariah sendiri, dari beberapa tahun belakang, industri keuangan berlaber syariah mulai marak bermunculan, baik bank syariah, pembiayaan syariah, dan lembaga keuangan syariah laiinya. Hal tersebut menunjukan bisnis pada industry keuangan syariah sedang banyak diminati dan menjanjikan. Indonesia sendiri merupakan negara berpenduduk muslim terbesar di dunia, dengan demikian Indonesia merupakan ladang pasar yang sangat bagi industri-industri bisnis berlabel syariah.

Bagi umat Islam sendiri, merupakan kewajiban untuk patuh pada aturan-aturan yang sudah ditetapkan oleh syariah, termasuk dalam berasuransi, dimana setiap transaksi atau akad yang dilakukan tidak boleh bertentangan dengan ketentuan syariah. Asuransi konvensional mengandung bentuk-bentuk tansaksi yang dilarang oleh syariah,

Dalam Dewi (2007) dijelaskan diantara praktek-praktek yang dilarang oleh syariah pada asuransi konvensional yang pertama adalah adanya gharar (ketidak jelasan), kontrak atau transaksi pada asuransi konvensional adalah dengan akad tabadduli, yaitu akad pertukaran antara premi dengan pertanggunangan, karenanya gharar dapat terjadi pada ketidak jelasan ada atau tidaknya klaim yang akan diperoleh nasabah dari perusahaan asuransi. Selain itu dalam asuransi konvensional adanya maysir atau gambling, terlihat apabila selama masa perjanjian peserta tidak mengalami musibah atau kecelakaan, maka peserta tidak berhak mendapatkan apa-apa termasuk termasuk premi yang disetornya. Sedangkan, keuntungan diperoleh ketika peserta yang belum lama menjadi anggota (jumlah premi yang disetor sedikit) menerima dana pembayaran klaim yang jauh lebih besar. Praktek lain yang dilarang syariah pada asuransi konvensional adalah adanya riba, Dalam cara perusahaan asuransi konvensional melakukan usaha dan investasi dimana meminjamkan dana premi yang terkumpul atas dasar bunga.

Praktek atau tansaksi asuransi konvensional yang terlarang dalam syariah di atas telah dihilangkan pada asuransi syariah, dimana pada akadnya dirubah menjadi taawuni atau tolong-menolong yang tergolong pada akad tabarru', sehingga gharar yang terjadi tidak berdampak pada akad tersebut. Dengan demikian maisir atau gambling juga hilang dan konsep pada asuransi syariah, dana premi (kontribusi) yang terkumpul diinvestasikan dengan prinsip bagi hasil, terutama mudharabah dan musyarakah.

Dalam memutuskan sesuatu, seseorang dapat dipengaruhi dua macam faktor utama, faktor internal yaitu faktor yang terkait dengan kebutuhan psikologis, latar belakang pendidikan, alat indera, kepribadian dan pengalaman penerimaan diri serta keadaan individu pada waktu tertentu (Gibson, Ivancevich, \& Donnelly, 1989). Untuk faktor internal ini sub variable yang digunakan adalah pengetahuan tentang syariah. Faktor yang kedua adalah faktor eksternal, faktor ini digunakan untuk obyek yang dipersepsikan atas orang atau keadaan, lingkungan, kekuatan rangsangan akan turut menentukan didasari atau tidaknya rangsangan tersebut. Untuk 
faktor ini menggunakan sub variable produk, premi (kontribusi) dan promosi asuransi syariah.

\subsection{SYARIAH}

Kata syariah berasal dari dahasa Arab, syariah bentuk masdar dari شرع yang memiliki arti jalan ke sebuah mata air. sedangkan secara terminology syariah adalah sesuatu yang ditentukan oleh Allah SWT untuk hambanya dari hukum-hukum yang diturunkan melalui nabi Muhammad SAW, baik dalam hukum-hukum aqidah maupun hukum-hukum muamalah untuk kebahagiaan mereka baik di dunia maupun di akhirat (Al-Sa'di, 2013). Syariah merupakan sebuah nilai tersendiri dalam menaati ajaran agama. Jalaluddin (2007) menjelaskan bahwa agama merupakan bentuk kepercayaan dan keyakinan terhadap sesuatu yang bersifat supranatural (adikodrati), hal ini membuat kayakinan tersebut menyertai manusia dalam ruang lingkup kehidupan yang luas. Agama menyertai seluruh nilai kehidupan secara pribadi dan sosial bermasyarakat. Selain itu agama juga akan memberikan dampak bagi kehidupan sehari-hari. Agama berpengaruh motivasi dan mendorong individu untuk melakukan sesuatu, agama dengan landasan keyakinan dinilai memiliki unsur kesucian yang berpengaruh pada ketaatan, keterkaitan ini akan memberi pengaruh diri seseorang untuk berbuat sesuatu, mepertimbangkan sesuatu dan dalam memutuskan sesusatu.

\subsection{PRODUK}

Kotler \& Keller (2016) menjelaskan produk merupakan suatu benda maupun jasa yang ditawarkan ke pasar yang diharapkan dapat memenuhi kebutuhan dan keinginn pelanggan. Produk ialah seperangkat atribut baik berwujud maupun tidak berwujud, termasuk didalamnya masalah harga, nama baik perusahan, dan pelayanan perusahaan yang diterima oleh pembeli untuk memuaskan. Dalam penelitian Sofhian (2017) menerangkan bahwa kualitas produk dan religiusitas mempunyai pengaruh positif dan signifikan terhadap keputusan nasabah memilih asuransi syariah, jika kualitas produk ditingkatkan atau diturunkan sebesar satu satuan maka keputusan nasabah memilih asuransi syariah akan meningkat atau menurun sesuai dengan produk dan tingkat religiusitas dalam berasuransi syariah. Hal tersebut sejalan dengan penelitian yang dilakukan oleh Marwa, Sumarwan, \& Nurmalina, (2015) . Hasil penelitian menunjukkan bahwa setidaknya ada lima bauran pemasaran memiliki pengaruh terhadap keputusan pembelian asuransi jiwa, dan bauran produk merupakan variabel yang paling berpengaruh terhadap keputusan pembelian asuransi jiwa.

\subsection{PREMI (KONTRIBUSI)}

Undang-Undang No. 40 Tahun 2014 tentang Perasuransian mendefinisikan pengertian premi adalah "sejumlah uang yang ditetapkan oleh Perusahaan Asuransi atau perusahaan reasuransi dan disetujui oleh pemegang polis untuk dibayarkan berdasarkan perjanjian asuransi atau perjanjian reasuransi, atau sejumlah uang yang ditetapkan berdasarkan ketentuan peraturan perundang- 
undangan yang mendasari program asuransi wajib untuk memperoleh manfaat". Lebih lanjut, pengertian kontribusi dalam undang-undang tersebut adalah "sejumlah uang yang ditetapkan oleh perusahaan asuransi syariah atau perusahaan reasuransi syariah dan disetujui oleh pemegang polis untuk dibayarkan berdasarkan perjanjian asuransi syariah atau perjanjian reasuransi syariah untuk memperoleh manfaat dari dana tabarru' dan/atau dana investasi peserta dan untuk membayar biaya pengelolaan atau sejumlah uang yang ditetapkan berdasarkan ketentuan peraturan perundang-undangan yang mendasari program asuransi wajib untuk memperoleh manfaat". premi asuransi adalah uang pertanggungan merupakan pembayaran sejumlah uang yang dilakukan pihak tertanggung kepada penanggung untuk mengganti kerugian, kerusakan, atau kehilangan keuntungan yang diharapkan akibat timbulnya perjanjian atas pemindahan risiko dari tertanggung kepada penanggung (Nopriyansyah, 2016).

Dalam asuransi syariah, premi lebih dikenal sebagai kontribusi. Asuransi syariah mempunyai perbedaan yang mencolok pada pengelolaan dana kontribusi tersebut, dimana setiap peserta asuransi sejak awal mempunyai semangat saling tolong menolong dan melindungi satu sama lain antar peserta, dana kontribusi yang disetorkan akan disisihkan sebagiannya sebagai dana kebijakan yang disebut tabarru'. Hal ini yang membuatnya berbeda dengan asuransi konvensional, menurut Soemitra (2009) sistem asuransi syariah ini tidak menggunakan pengalihan risiko (risk transfer) dimana perusahaan asuransi harus membayar kontribusi peserta, tetapi menggunakan sistem pembagian risiko (risk sharing) dimana peserta satu dan lainnya saling menanggung jika salah satu dari peserta mendapat musibah.

\subsection{PROMOSI}

Pengertian promosi dalam Kotler \& Armstrong, (2013) "promotion means activities that communicate the merits of the product and persuade target customers to buy it. Artinya promosi merupakan kegiatan yang mengkomunikasikan manfaat dari sebuah produk dan membujuk target konsumen untuk membeli produk tersebut", sedangkan Cummins (1991) mendefinisikan "promosi sebagai serangkaian teknik yang digunakan untuk mencapai sasaran penjualan atau pemasaran dengan menggunakan biaya yang efektif, dengan memberikan nilai tambah pada produk atau jasa baik kepada perantara atau pemakai langsung. Biasanya tidak dibatasi dalam jangka waktu tertentu".

Faktor-faktor masyarakat dalam memilih untuk memutuskan sesuatu mempunyai beberapa aspek penting peritimbangan, termasuk dalam memilih untuk berasuransi syariah. Fitria, (2014) dalam penelitiannya menjelaskan bahwa faktor syariah, produk, harga, promosi, lokasi, sumber daya manusia, proses, dan bukti fisik secara bersama-sama berpengaruh terhadap loyalitas nasabah asuransi syariah.

Pengertian asuransi syariah sendiri mengandung arti menanggung suatu kerugian yang terjadi. Sementara dalam bahasa Arab, asuransi terambil dari kata أمن, yang berarti aman, yaitu berkenaan dengan ketenangan jiwa 
dan meniadakan rasa takut. Menurut Sula (2004) yaitu asuransi merupakan cara atau metode untuk memelihara manusia dalam menghindari risiko (ancaman) bahaya yang beragam yang akan terjadi dalam hidupnya atau dalam aktivitas ekonominya.

Dari pengertian di atas, sebenarnya perbedaan utama dari asuransi syariah dan konvensional terletak pada tujuan dan landasan operasional. Dari sisi tujuan, asuransi syariah bertujuan saling menolong (ta' $\hat{a} w u n \hat{\imath})$ sedangkan dalam asuransi konvensional tujuannya penggantian (tabâdulî). Pada aspek landasan operasional, asuransi konvensional melandaskan pada peraturan perundangan, sementara asuransi syariah melandaskan pada peraturan perundangan dan ketentuan syariah (Maksum, 2011).

Dalam hal ketentuan syariah, asuransi syariah dibatasi dalam kegiatannya oleh larangan-larangan syariah, di antaranya larangan mempraktikkan riba dalam bentuk apapun, menghindarkan praktik perjudian, ketidakpastian, dan ketidakjelasan (maysir, gharar, jahâlah), dan berinvestasi dalam bidang yang halal. Selain itu, dalam konteks Indonesia, asuransi syariah wajib memiliki dewan pengawas syariah yang bertugas mengawasi kesesuaian praktik perusahaan asuransi dengan ketentuan syariah.

Menurut Saharuddin, (2014) Pada perusahaan asuransi shariah hal yang perlu benar-benar diperhatikan adalah amanah dan kejujuran, karena tujuan utama yang ingin dicapai dalam bisnis industri perusahaan dalam mencari keuntungan adalah saling tolong menolong untuk kebaikan dan ketaqwaan. Bagaimana pun juga, perusahaan asuransi shariah adalah lembaga bisnis bukan bank yang beroprasional dalam bidang produk jasa dan pengelolaan risiko yang menawarkan janji-janji adanya mitigasi risiko dan ganti rugi.

\section{METODE PENELITIAN}

Metode penelitian yang digunakan adalah analisa kuantitatif. Untuk populasi dan sampel adalah masyarakat Jabodetabek Metode ini menggunakan Teknik Convenience Sampling dikarenakan dapat menentukan sampel berdasarkan kebetulan saja, anggota populasi yang ditemui peneliti dan bersedia menjadi responden dijadikan sampel (Suliyanto, 2018). Dengan menyebarkan kuesioner kepada masyarakat Jabodetabek. Format kuesioner yang digunakan pada penelitian ini dibagi menjadi dua bagian. Bagian yang pertama berisi tentang informasi identitas profil responden, Sedangkan bagian kedua dari kuesioner berkaitan dari faktor - faktor yang yang mempengaruhi dalam memutuskan untuk berasuransi syariah.Untuk analisis data menggunakan PLS (Partial Least Square). suatu tekhnik statistik multivariat yang bisa menangani banyak variabel respon dan variabel eksplanatori sekaligus. PLS merupakan alternatif yang baik untuk metode analisis regresi berganda dan regresi komponen utama karena metode PLS bersifat lebih robust, artinya parameter model tidak banyak berubah ketika sampel baru diambil dari total populasi. 
Pada penelitian ini akan dilakukan pengujian hipotesis menggunakan software Partial Least Square (SmartPLS) 3.0. metode alternatif analisis dengan Structural Equation Modelling (SEM) yang berbasis variance. Keunggulan metode ini adalah tidak memerlukan asumsi dan dapat diestimasi dengan jumlah sampel yang relatif kecil. Model structural penelitian ini dapat dilihat pada Gambar 1.

Gambar 1 menjelaskan bahwa seluruh konstruk diukur dengan 3 buah indikator. konstruk keputusan (K) diukur dengan 3 indikator, yaitu K1, K2 dan K3. Konstruk syariah (SY), diukur dengan indikator SY1, SY2 dan SY3. Konstruk produk (PRO) diukur dengan indokator PRO1, PRO2, dan PRO3. Konstruk premi/kontribusi (PRE) diukur dengan PRE1, PRE2, dan PRE 3. Demikian dengan konstruk promosi, diukur dengan indokator M1, M2 dan M3. Arah panah antara indikator dengan kontruk laten adalah menuju indikator yang menunjukkan bahwa penelitian menggunakan indikator reflektif yang relatif sesuai untuk mengukur persepsi. Hubungan yang akan diteliti (hipotesis) dilambangkan dengan anak panah antara konstruk.

Gambar 1. Hasil model output PLS

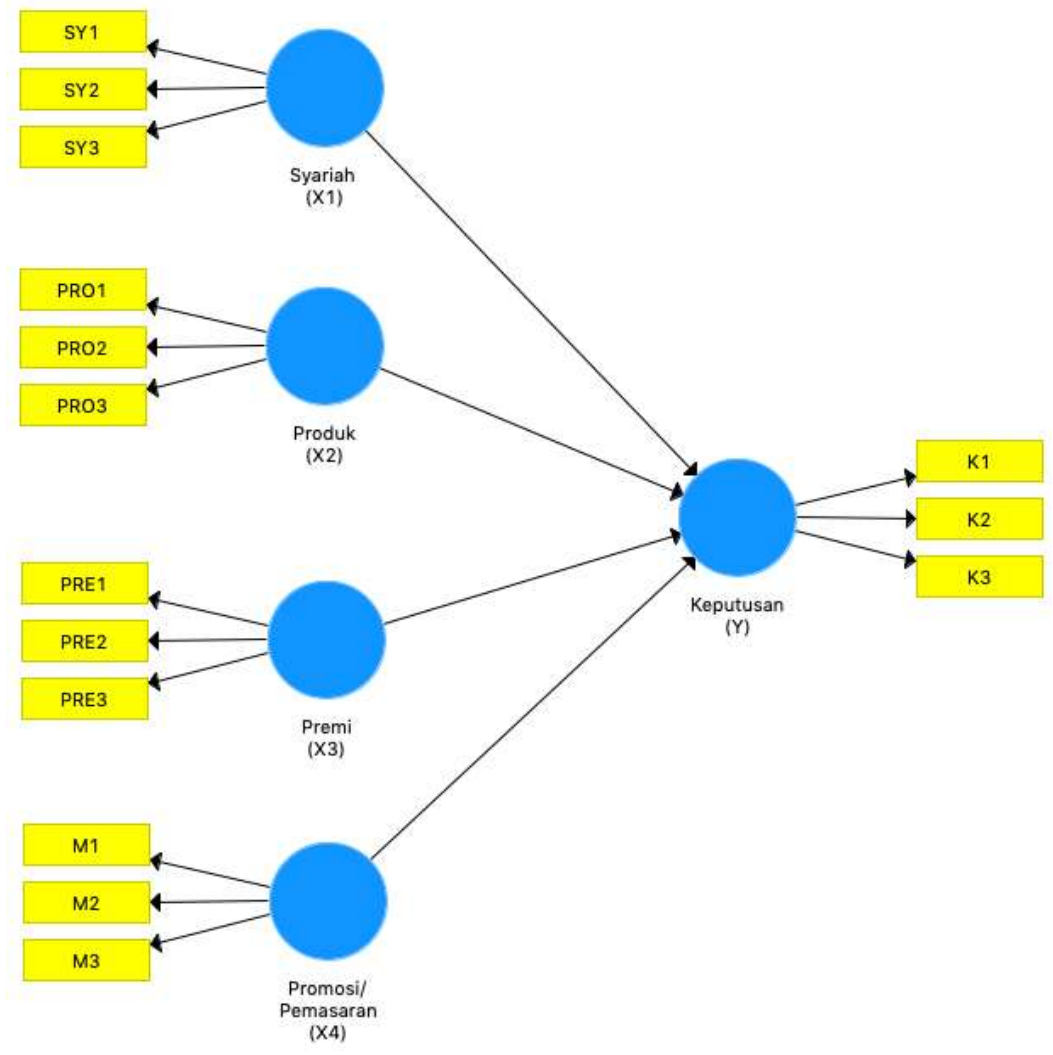




\section{ANALISIS DATA DAN PEMBAHASAN}

\subsection{PENGUJIAN MODEL}

\subsubsection{Uji Validitas}

Suatu indikator dinyatakan valid jika mempunyai loading factor di atas 0,5 terhadap konstruk yang dituju. Pada tabel diatas menunjukkan bahwa semua nilai loading factor diatas 0,5 , hal tersebut Berarti menunjukan indikator yang dipergunakan dalam penelitian ini adalah valid. Nilai paling kecil adalah sebesar 0.592 untuk indikator PRO1. Berarti indikator yang dipergunakan dalam penelitian ini adalah valid atau telah memenuhi convergent validity.

Tabel 3. Output Loading Factor

\begin{tabular}{|c|c|c|c|c|c|}
\hline & $\begin{array}{c}\text { Keputusan } \\
(\mathrm{Y})\end{array}$ & $\begin{array}{l}\text { Premi } \\
(\mathrm{X} 3)\end{array}$ & $\begin{array}{l}\text { Produk } \\
(\mathrm{X} 2)\end{array}$ & $\begin{array}{c}\text { Promosi/Pemasaran } \\
(\mathrm{X} 4)\end{array}$ & $\begin{array}{c}\text { Syariah } \\
(\mathrm{X} 1)\end{array}$ \\
\hline K1 & 0.851 & & & & \\
\hline $\mathrm{K} 2$ & 0.744 & & & & \\
\hline K3 & 0.775 & & & & \\
\hline M1 & & & & 0.756 & \\
\hline M2 & & & & 0.793 & \\
\hline M3 & & & & 0.945 & \\
\hline PRE1 & & 0.887 & & & \\
\hline PRE2 & & 0.886 & & & \\
\hline PRE3 & & 0.887 & & & \\
\hline PRO1 & & & 0.592 & & \\
\hline PRO2 & & & 0.890 & & \\
\hline PRO3 & & & 0.905 & & \\
\hline SY1 & & & & & 0.811 \\
\hline SY2 & & & & & 0.770 \\
\hline SY3 & & & & & 0.821 \\
\hline
\end{tabular}

Sumber: Data diolah

Tabel 4 menunjukan nilai AVE diatas 0,5 untuk semua konstruk yang terdapat pada model penelitian. Nilai terendah AVE adalah sebesar 0.641 pada konstruk Keputusan. Maka dapat disimpulkan bahwa seluruh konstruk Keputusan, Premi/Kontribusi, Produk, Promosi dan Syariah adalah valid.

\subsubsection{Uji Reliabilitas}

Uji reliabilitas dapat dilakukan dengan melihat nilai composite reliability dari indikator yang mengukur konstruk. Hasil composite reliability akan menunjukkan nilai yang memuaskan jika di atas 0,7 , dan bisa diperkuat dengan Cronbach's Alpha. 
Tabel 4. Uji Validitas

\begin{tabular}{ll}
\hline & AVE \\
\hline Keputusan (Y) & 0.641 \\
\hline Premi/Kontribusi (X3) & 0.740 \\
\hline Produk (X2) & 0.654 \\
\hline Promosi (X4) & 0.702 \\
\hline Syariah (X1) & 0.642 \\
\hline
\end{tabular}

Nilai pada Tabel 5 menunjukkan bahwa seluruh konstruk menunjukan nilai composite reliability $>0,7$, hal ini berarti bahwa nilai semua konstruk pada model yang diestimasi memenuhi kriteria discriminant validity.

Tabel 5. Composite Reliability

\begin{tabular}{lc}
\hline & Composite Reliability \\
\hline Keputusan (Y) & 0.843 \\
\hline Premi/Kontribusi (X3) & 0.895 \\
\hline Produk (X2) & 0.846 \\
\hline Promosi (X4) & 0.875 \\
\hline Syariah (X1) & 0.843 \\
\hline
\end{tabular}

Nilai yang disarankan adalah di atas 0,6 dan pada Tabel 6 menunjukan nilai Cronbach alpha paling rendah adalah sebesar 0,727 pada konstruk syariah.

Tabel 6. Cronbach Alpha

\begin{tabular}{lc}
\hline & Cronbach Alpha \\
\hline Keputusan (Y) & 0.744 \\
\hline Premi/Kontribusi (X3) & 0.826 \\
\hline Produk (X2) & 0.749 \\
\hline Promosi (X4) & 0.809 \\
\hline Syariah (X1) & 0.727 \\
\hline
\end{tabular}

\subsubsection{Uji R SQUARE}

Berdasarkan

Tabel 7, R-Square Adjusted adalah sebesar 0,305 dengan demikian menunjukan pengaruh premi/kontribusi, produk, promosi dan syariah terhadap keputusan sebesar 30,5\% dan sisanya sebesar 69,5\% dipengaruhi oleh faktor lain. 
Tabel 7. Nilai R Square dan R Square Adjusted

\begin{tabular}{ccc}
\hline & R Square & R Square Adjusted \\
\hline Keputusan $(\mathrm{Y})$ & 0.333 & 0.305 \\
\hline \multicolumn{3}{c}{ Sumber: data diolah }
\end{tabular}

\subsubsection{Uji Hipotesis}

Tabel 8 menunjukkan bahwa hubungan antara PRE dengan $\mathrm{K}$ adalah tidak signifikan dengan T-statistik sebesar 0,618 $(<1,96)$. Nilai original sample estimate adalah positif yaitu sebesar 0,069 yang menunjukkan bahwa arah hubungan antara PRE dengan $\mathrm{K}$ adalah positif. Dengan demikian hipotesis H1 dalam penelitian ini yang menyatakan bahwa "Premi berpengaruh terhadap Keputusan" diterima.

Tabel 8. Hasil Nilai Koefisien Analisis Jalur

\begin{tabular}{lccccc}
\hline & $\begin{array}{c}\text { Original } \\
\text { Sample } \\
(\mathrm{O})\end{array}$ & $\begin{array}{c}\text { Sample } \\
\text { Mean } \\
(\mathrm{M})\end{array}$ & $\begin{array}{c}\text { Standard } \\
\text { Deviation } \\
(\text { STDEV })\end{array}$ & $\begin{array}{c}\text { T Statistics } \\
(|0| \text { STDEV })\end{array}$ & $\begin{array}{c}\mathrm{P} \\
\text { Values }\end{array}$ \\
$\begin{array}{l}\text { Premi/Kontribusi } \\
->\text { Keputusan }\end{array}$ & 0.069 & 0.066 & 0.112 & 0.618 & 0.537 \\
\hline $\begin{array}{l}\text { Produk-> } \\
\text { Keputusan }\end{array}$ & 0.306 & 0.297 & 0.105 & 2.905 & 0.004 \\
\hline $\begin{array}{l}\text { Promosi } \\
\text { Keputusan }\end{array}->$ & -0.037 & -0.022 & 0.144 & 0.256 & 0.798 \\
\hline $\begin{array}{l}\text { Syariah } \\
\text { Keputusan }\end{array}->$ & 0.401 & 0.413 & 0.075 & 5.356 & 0.000 \\
\hline
\end{tabular}

Hubungan antara PRO dengan $\mathrm{K}$ adalah signifikan dengan T-statistik sebesar 2,905 (> 1,96). Nilai original sample estimate adalah positif yaitu sebesar 0,306 yang menunjukkan bahwa arah hubungan antara PRO dengan $\mathrm{K}$ adalah positif. Dengan demikian hipotesis H2 dalam penelitian ini yang menyatakan bahwa"Produk berpengaruh terhadap Keputusan" diterima.

Hubungan antara $\mathrm{M}$ dengan $\mathrm{K}$ adalah tidak signifikan dengan $\mathrm{T}$ statistik sebesar $-0,256(<1,96)$. Nilai original sample estimate adalah negatif yaitu sebesar -0,037 yang menunjukkan bahwa arah hubungan antara $\mathrm{M}$ dengan KT adalah negatif. Dengan demikian hipotesis H3 dalam penelitian ini yang menyatakan bahwa "Promosi berpengaruh terhadap Keputusan" ditolak.

Hubungan antara SY dengan K adalah signifikan dengan T-statistik sebesar 5,356 (> 1,96). Nilai original sample estimate adalah positif yaitu sebesar 0,401 yang menunjukkan bahwa arah hubungan antara SY dengan K adalah positif. Dengan demikian hipotesis $\mathrm{H} 4$ dalam penelitian ini yang menyatakan bahwa "Syariah berpengaruh terhadap Keputusan" diterima. 
Berdasarkan penelitian ini menunjukan bahwa premi/kontribusi tidak mempunyai pengaruh signifikan dengan keputusan. Hal ini ditunjukan dengan nilai T-statistik sebesar 0,618 $(<1,96)$. Mempunyai Nilai original sample estimate adalah positif yaitu sebesar 0,069 yang menunjukkan bahwa arah hubungan antara premi dengan keputusan adalah positif. Kesimpulan dari data tersebut bahwa premi/kontribusi tidak mempunyai kontribusi signifikan dengan keputusan masyarakat dalam memutuskan untuk berasuransi syariah. Hal tersebut tidak sejalan dengan hasil penelitian (Kurniawaty, 2017) yang dilakukan pada asuransi konvensial, menyatakan bahwa tarif premi memiliki pengaruh positif dan signifikan terhadap minat beli.

Besaran tarif premi atau kontribusi seyogyanya mempunyai perngaruh terhadap minat atau keputusan masyarakat dalam berasuransi syariah, namun jika dilihat dalam penelitian ini menunjukan belum adanya tarif atau besaran kontribusi yang kompetitif jika dibandingkan dengan asuransi konvensional, sehingga premi (kontribusi) belum mempunyai pengaruh yang signifikan terhadap keputusan masyarakat dalam memilih asuransi syariah. Dengan demikian dapat diartikan bahwa kenaikan atau penurunan tarif premi (kontribusi) tidak mempunyai pengaruh yang signifikan dalam menentukan minat calon peserta asuransi dalam berasuransi syariah.

\subsubsection{Produk Terhadap Keputusan}

Berdasarkan penelitian ini menunjukan bahwa produk mempunyai pengaruh signifikan terhadap keputusan. Hal ini ditunjukan dengan dengan nilai $\mathrm{T}$ statistik sebesar 2,905 (> 1,96). Nilai original sample estimate adalah positif yaitu sebesar 0,306 yang menunjukkan bahwa arah hubungan antara produk dengan keputusan adalah positif. Kesimpulan yang dapat diambil bahwa kualitas produk mempengaruhi keputusan masyarakat dalam berasuransi syariah. Hal ini sejalan dengan hasil penelitian yang dilakukan di Prudential Life Ansurance Cabang Kota Gorontalo oleh Sofhian dan Suleman (2017), menyatakan bahwa kualitas produk berpengaruh positif dan signifikan terhadap keputusan nasabah memilih asuransi syariah.

Setiap peningkatan baik pada sisi kualitas maupun kwantitas produk oleh perusahaan asuransi syariah, maka mempunyai 30,6\% pengaruh yang signifikan terhadap calon nasabah dalam memutuskan untuk berasuransi syariah. Dengan demikian dapat diartikan bahwa semakin tinggi kwalitas produk yang ditawarkan maka semakin besar minat masyarakat dalam berasuransi syariah.

\subsubsection{Promosi Terhadap Keputusan}

Berdasarkan penelitian ini menunjukan bahwa promosi tidak mempunyai pengaruh signifikan terhadap keputusan. Hal ini ditunjukan dengan nilai Tstatistik sebesar $0,256(<1,96)$. Nilai original sample estimate adalah negatif yaitu sebesar -0,037 yang menunjukkan bahwa arah hubungan antara promosi 
dengan keputusan adalah negatif. Dengan demikian dapat diambil kesimpulan bahwa promosi belum mempunyai pengaruh terhadap keputusan masyarakat dalam berasuransi syariah, dimana bentuk promosi atau pemasaran yang ditawarkan kurang mempunyai peran atau andil khusus dalam keputusan masyarakat untuk mengikuti asuransi syariah.

Hal Ini sejalan dengan penelitian yang dilakukan oleh Santoso, (2016) pada PT Takaful Cabang Gedong Kuning, penelitian ini menyatakan bahwa promosi tidak berpengaruh terhadap permintaan asuransi syariah, hal ini dikarenakan promosi yang dilakukan perusahaan asuransi syariah sangat terbatas pada personal selling, yang terdiri dari interaksi pribadi dengan pelanggan dan calon pelanggan untuk menghasilkan pelanggan dan menjaga hubungan pelanggan. Selain itu salah satu kelemahan personal selling dalam promosi adalah memerlukan waktu yang lama serta membutuhkan biaya yang relatif besar.

\subsubsection{Syariah Terhadap Keputusan}

Berdasarkan penelitian ini menunjukkan bahwa syariah mempunyai pengaruh signifikan terhadap keputusan. Hal ini ditunjukan dengan T-statistik sebesar 5,356 (> 1,96). Nilai original sample estimate adalah positif yaitu sebesar 0,401 yang menunjukkan bahwa arah hubungan antara syariah dengan keputusan adalah positif. Sehingga dapat diambil kesimpulan bahwa pemahaman tentang kesyariahan mempunyai pengaruh yang signifikan terhadap masyarakat dalam mengambil keputusan dalam berasuransi syariah. Pemahaman tentang syariah memang menjadi salah satu faktor terkuat sebagai umat muslim yang wajib mengikuti atau memperhatikan peraturanperaturan dalam bermuamalah, termasuk dalam memutuskan untuk berasuransi syariah.

Hal tersebut sejalan dengan penelitian Mohamad Abdul Hamid, (2009), Akhter \& Hussain, (2012) dan (Schmidt, n.d.). Seseorang yang faham ilmu agama (syariah) dan mengamalkannya dengan ikhlas maka ia akan memutuskan memilih sesuatu yang diperbolehkan oleh syariah dan menjauhi sesuatu yang dilarang syariah, tentu hal tersebut untuk menjaga keimanannya dalam mengamalkan syariah.

Dari hasil penelitian ini dapat diambil pengertian bahwa pengaruh masyarakat dalam memilih untuk berasuransi syariah sangat dipengaruhi oleh kesyariahan itu sendiri, dimana masyarakat tersadarkan akan pentingnya bermuamalah sesuai dengan nilai-nilai syariah atas dasar keimanan yang dianut. Dengan demikian peningkatan branding kesyariahan baik terhadap perusahaan asuransi maupun terhadap produk-produk asuransi yang ditawarkannya, maka akan sangat mempengaruhi masyarakat dalam berasuransi.

\section{KESIMPULAN}

Berdasarkan dari hasil penelitian dan analisis Partial Least Square (PLS) dapat ditarik kesimpulan bahwa tingkat partisipasi atau keputusan masyarakat 
di Jabodetabek dilihat dari indikator premi/kontribusi dan promosi masih kurang mempunyai pengaruh, hal ini dilihat karena kurang menonjolnya perusahaan asuransi syariah dalam variasi premi/kontribusi untuk menyentuh pada kalangan mikro dan juga pemasaran yang masih menggunakan keagenan sebagai pemasar, sehingga tidak ada pembanding dengan konvensional. Sedangkan untuk indicator produk dan syariah, sudah cukup baik diterima atau mempunyai pengaruh signifikan terhadap keputusan masyarakat dalam berasuransi syariah, karena dari kedua sisi tersebut memang mempunyai karakteristik tersendiri bagi asuransi syariah. Diharapkan Untuk perusahaan asuransi syariah harus lebih mensosialisasikan dan mempunyai aneka pilihan dalam menentukan jumlah premi/kontribusi asuransi syariah dengan menyesuaikan dengan kemampuan masyarakat untuk menjadi peserta asuransi syariah.

\section{DAFTAR PUSTAKA}

Akhter, W., \& Hussain, T. (2012). Takāful standards and customer perceptions affecting takāful practices in Pakistan: a survey. International Journal of Islamic and Middle Eastern Finance and Management. https://doi.org/10.1108/17538391211255214

Al-Sa'di, I. bin A. (2013). بنه المستشرقين وموقف الإسلامية الأمة تميز في دراسات.pdf. Qatar: Wizarah Awqaf wa Su'un Islamiyah.

Cummins, J. (1991). Promosi Penjualan. Jakarta: Binarupa Aksara.

Dewan Syariah Nasional (DSN), M. U. I. (2001). Fatwa Dewan Nasional No. 21/DSN-MUI/X/2001 Tentang Pedoman Umum Asuransi Syariah. Jakarta.

Dewi, G. (2007). Aspek-aspek Hukum dalam Perbankkan dan Perasuransian Syariah di Indonesia. Jakarta: Kencana.

Fitria, I. (2014). Pengaruh Penerapan Nilai Syariah dan Bauran Pemasaran Jasa Terhadap Loyalitas Nasabah Pada Bumiputera Syariah Cabang Yogyakarta. Universitas Islam Negeri Sunan Kalijaga.

Gibson, J. L., Ivancevich, J. M., \& Donnelly, J. H. (1989). Organisasi : perilaku, struktur, proses. Jakarta: Binarupa Aksara.

Ichsan, N., Syarif, U., \& Jakarta, H. (2016). Peluang Dan Tantangan Inovasi Produk Asuransi Umum Syariah. Jurnal Ekonomi Islam, 7(2), 131156.

Jalaluddin, \& Idi, A. (2007). Filsafat Pendidikan: Manusia, Filsafat dan Pendidikan. Jogjakarta: Ar-Ruzz Media.

Kotler, P., \& Armstrong, G. (2013). Principles of Marketing 15th Global Edition. Pearson Education Limited.

Kotler, P., \& Keller, K. L. (2016). Marketing Management. Global Edition 
(5th ed.). https://doi.org/10.1080/08911760903022556

Kurniawaty, E. (2017). Pengaruh Citra Perusahaan dan Tarif Premi Terhadap Minat Beli Yang Berdampak Pada Kepuasan Pelanggan di PT Asuransi Cigna Jakarta. Jurnal KREATIF: Pemasaran, Sumberdaya Manusia Dan Keuangan, Vol. 5 (1), 16.

Maksum, M. (2011). Pertumbuhan Asuransi Syariah di Dunia dan Indonesia. Jurnal Al-Iqtishod, III (1), 37.

Marwa, S., Sumarwan, U., \& Nurmalina, R. (2015). Bauran Pemasaran Memengaruhi Keputusan Konsumen Dalam Pembelian Asuransi Jiwa Individu. Jurnal Ilmu Keluarga \& Konsumen, 7(3), 190.

Mohamad Abdul Hamid, M. S. O. (2009). A study on the level of knowledge and understanding among muslims towards the concepts, Arabic and shariah terms in islamic insurance (Takaful). European Journal of Social Sciences.

Nopriyansyah, W. (2016). Asuransi Syariah, Berkah Terakhir Yang Tak Terduga. Yogyakarta: Andi Offset.

Ridlwan, A. A. (2017). Asuransi Perspektif Hukum Islam. Jurnal Hukum Dan Ekonomi Syariah, 04.

Saharuddin, D. (2014). Asuransi Syariah dalam Praktek (Studi Analisis Terhadap Shariah Compliance). ESENSI. https://doi.org/10.15408/ess.v4i3.2438

Santoso, H. (2016). Pengaruh Promosi, Premi, Pendapatan Nasabah, dan Tingkat Pendidikan Nasabah terhadap Permintaan Asuransi pada PT Takaful Cabang Gedong Kuning. Universitas Islam Negeri Sunan Kalijaga.

Schmidt, A. P. (n.d.). The Impact of Cognitive Style, Consumer Demograpics and Cultural Values on The Acceptance od Islamic Insurance Products Among American Consumers. International Journal of Bank Marketing, 37 (2).

Soemitra, A. (2009). Bank dan Lembaga Keuangan Syariah. Jakarta: Kencana.

Sula, M. S. (2004). Asuransi Syariah (Life and General). Jakarta: Gema Insani.

Suliyanto. (2018). Metode Penelitian Bisnis Untuk Skripsi, Tesis, Dan Disertasi. Yogyakarta: Andi Offset. 